\title{
PENGARUH PEMBERIAN PH SUBSTRAT TERHADAP KADAR SERAT, VITAMIN C, DAN TINGKAT PENERIMAAN NATA DE CASHEW (ANACARDIUM OCCIDENTALE L.)
}

\author{
Ratuca Steffie Sutanto, Arintina Rahayuni* ${ }^{*}$ \\ Program Studi Ilmu Gizi Fakultas Kedokteran Universitas Diponegoro \\ Jl.Dr.Sutomo No.14, Semarang, Telp (024) 8453708, Email : gizifk@undip.ac.id
}

\begin{abstract}
Background: Cashew apple which high in vitamin $C$ but rarely consumed is to be used as a likable food product such as nata. Nata that made from cashew apple is called nata de cashew. Nata contained high level of fiber. The taste, fiber and vitamin $C$ content of nata de cashew is affected by $\mathrm{pH}$. Therefore, conducted research about the effect of substrate $\mathrm{pH}$ on fiber and vitamin $C$ content and the level of acceptance of nata de cashew.

Objective: Analyze fiber and vitamin C content, and level of acceptance of nata de cashew with various substrate $p H$.

Methods: An experimental study with a complete random program with 3 treatments that A3, B3, C3 as substrate with $\mathrm{pH} \mathrm{3;} \mathrm{A4,} \mathrm{B4,} \mathrm{C4} \mathrm{as} \mathrm{substrate} \mathrm{with} \mathrm{pH} 4$; A5, B5, C5 as substrate with $p H$ 5. The analyzes are fiber and vitamin $C$ content and the level of acceptance. Fiber content was obtained with gravimetric test. Vitamin $C$ content was obtained with dye test. The level of acceptance was obtained with hedonic test. Statistic anaylisis of fiber and vitamin C contenct were using independent T test while the level of acceptance was using Wilcoxon test.

Result: The result of fiber content of nata de cashew ranged $1.06 \%-4.57 \%$ while vitamin $C$ content of nata de cashew ranged $25.71 \%$ - $51.43 \mathrm{mg} \%$. Nata de cashew $\mathrm{pH} 3$ was failed to be formed. The various $\mathrm{pH}$ did not affect the fiber and vitamin $C$ content of nata de cashew. The result of acceptance test, color is affected by various pH but scent, texture, and taste are not affected by various $\mathrm{pH}$. The color of nata de cashew $\mathrm{pH} 4$ is preferred by the panelists. The panelists didn't like the scent of nata de cashew pH 4 and pH 5. The panelists liked the texture of nata de cashew $\mathrm{pH} 4$ and $\mathrm{pH}$ 5. The taste of nata de cashew is flavorless.

Conclusion: Fiber and vitamin $C$ content are not affected by $\mathrm{pH}$ variation. The result of level of acceptance is that various $\mathrm{pH}$ affected the color of nata de cashew but didn't affect scent, texture, and taste.
\end{abstract}

Keyword: fiber content; vitamin C content; nata de cashew; cashew apple; $p H$

\begin{abstract}
ABSTRAK
Latar Belakang: Buah semu jambu mete tinggi vitamin C namun jarang dikonsumsi karena rasanya sepat. Buah tersebut ingin dimanfaatkan menjadi suatu produk makanan yang disukai. Salah satu pemanfaatan jambu mete adalah nata. Nata yang terbuat dari bahan dasar sari buah jambu mete disebut juga nata de cashew. Nata merupakan produk makanan tinggi serat. Rasa sepat, kadar serat, dan kadar vitamin C dipengaruhi oleh pH. Oleh karena itu dilakukan penelitian tentang pengaruh $p H$ substrat terhadap kadar serat, vitamin $C$, dan tingkat penerimaan nata de cashew.
\end{abstract}

Tujuan: Menganalisis kadar serat, vitamin C, dan tingkat penerimaan nata de cashew pada perlakuan pH substrat yang berbeda.

Metode: Merupakan penelitian eksperimental dengan rancangan acak lengkap untuk mengetahui kadar serat, vitamin $C$, dan tingkat penerimaan nata de cashew dengan 3 perlakuan pH substrat yaitu A3, B3, C3 untuk substrat nata dengan $\mathrm{pH} 3, \mathrm{A4}, \mathrm{B4}, \mathrm{C4}$ untuk substrat nata dengan $\mathrm{pH}$ 4, dan A5, B5, dan C5 untuk substrat nata dengan pH 5. Analisis yang dilakukan adalah menghitung kadar serat kasar, vitamin $C$, dan tingkat penerimaan. Kadar serat didapatkan dengan uji gravimetri. Kadar vitamin $C$ didapatkan dengan uji dye. Tingkat penerimaan dilakukan dengan uji hedonik. Analisis statistik data kadar serat dan vitamin $C$ menggunakan uji independent $T$ test sedangkan data tingkat penerimaan menggunakan uji Wilcoxon.

Hasil: Hasil kadar serat nata de cashew berkisar antara 1,06\%-4,57\% sedangkan kadar vitamin C berkisar antara 25,71 - 51,43 mg\%. Nata de cashew dengan pH 3 gagal terbentuk. Variasi pH tidak mempengaruhi kadar serat dan kadar vitamin $C$ nata de cashew. Hasil dari uji tingkat penerimaan, variasi pH mempengaruhi warna nata de cashew namun tidak mempengaruhi aroma, tekstur, dan rasa nata de cashew. Warna nata de cashew dengan pH 4 lebih disukai dari pada nata de cashew dengan pH 5. Aroma nata de cashew pH 4 dan 5 tidak disukai oleh panelis. Tekstur nata de cashew pH 4 dan pH 5 disukai oleh panelis. Rasa nata de cashew pH 4 dan pH 5 tawar dan tidak terasa sepat dari sari buah jambu mete.

Simpulan: Kadar serat dan kadar vitamin C tidak dipengaruhi oleh variasi pH. Hasil uji tingkat penerimaan, variasi pH mempengaruhi warna nata de cashew namun tidak mempengaruhi aroma, tekstur, dan rasa.

${ }^{*}$ Penulis Penanggungjawab 
Kata kunci: kadar serat; kadar vitamin C; nata de cashew; jambu mete; $p H$

\section{PENDAHULUAN}

Jambu mete adalah tanaman yang berasal dari Brazil Tenggara dan sekarang telah tersebar di seluruh nusantara, buah ini disebut juga buah semu karena memiliki tangkai yang menggelembung menyerupai daging buah normal, sedangkan buah yang sebenarnya adalah buah batu yang berupa biji mete dengan kulit yang keras dan mengandung minyak. ${ }^{1}$ Jumlah produksi jambu mete di perkebunan rakyat Jawa Tengah pada tahun 2006 ke 2010 telah mengalami peningkatan sebesar $4,1 \%{ }^{2}$ Namun pemanfaatan buah tersebut di Indonesia masih dalam jumlah yang sangat terbatas. Hanya $20 \%$ yang sudah dimanfaatkan, sedangkan sisanya terbuang percuma. Buah ini memiliki kandungan karbohidrat yang cukup tinggi yaitu 15,3 gram per 100 gram. Kandungan Vitamin C juga sangat tinggi yaitu $197 \mathrm{mg}$ per 100 gram. $^{3}$

Jambu mete memiliki rasa sepat karena kandungan tanin yang cukup tinggi. Tanin dapat berkurang melalui beberapa perlakuan baik secara fisik, kimia ataupun keduanya. Jambu mete yang sepat dan kurang diminati warga akan diolah menjadi suatu produk makanan yang dapat disukai sehingga dapat meningkatkan pemanfaatan jambu mete yang tinggi zat gizi. Salah satu pemanfaatan jambu mete adalah nata de cashew.

Nata merupakan produk makanan yang tinggi serat. ${ }^{4}$ sehingga dapat dikonsumsi sebagai tambahan serat yang dibutuhkan dalam tubuh. Serat pada nata tergolong serat tidak larut air yang tidak dapat menurunkan kadar kolestrol dalam darah, namun dapat mencegah terjadinya kanker usus besar, susah buang air besar, obesitas, dan diabetes melitus. ${ }^{5}$ Berdasarkan hasil riset Puslitbang Gizi Depkes RI tahun 2001, rata-rata konsumsi serat penduduk Indonesia adalah 10,5 gram per hari. Angka ini menunjukkan bahwa penduduk Indonesia baru memenuhi kebutuhan seratnya sekitar 1/3 dari kebutuhan ideal rata-rata 30 gram setiap hari. ${ }^{6}$ Berdasarkan data Riskesdas 2007, diketahui bahwa prevalensi kurangnya konsumsi sayur dan buah pada penduduk usia > 10 tahun di Indonesia mencapai angka 93,6\%. ${ }^{7}$
Kualitas dan keberhasilan pembuatan dipengaruhi oleh beberapa faktor yaitu sumber karbon, sumber nitrogen, bibit nata, temperatur saat inkubasi, kebersihan alat, tempat fermentasi, waktu fermentasi, dan $\mathrm{pH}$ fermentasi. $\mathrm{pH}$ substrat sangat mempengaruhi kualitas nata karena bakteri Acetobacter xylinum dapat tumbuh pada suasana asam yaitu pada $\mathrm{pH} 3,5-7,5$ dan optimal pada $\mathrm{pH}$ 4,3. ${ }^{8}$ Berdasarkan penelitian, tanin yang terkandung dalam jambu mete dapat hilang pada

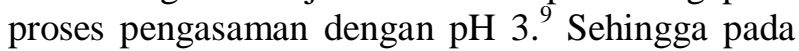
penelitian dilakukan perlakuan dengan $\mathrm{pH} 3,4$, dan 5 pada substrat nata. Pemberian $\mathrm{pH} 3$ untuk menginaktifkan tanin, pemberian $\mathrm{pH} 4$ untuk mengoptimalkan proses pembentukan nata. Karena selulosa memiliki sifat larut dalam asam konsentrasi tinggi, dilakukan pemberian $\mathrm{pH} 5$ untuk melihat kadar serat dan vitamin $\mathrm{C}$ nata de cashew yang terbaik dan tetap dapat diterima oleh panelis.

Perlakuan $\mathrm{pH}$ asam pada substrat nata de cashew diharapkan tidak terlalu mempengaruhi kandungan serat nata de cashew yang dihasilkan tetapi sebaliknya akan menurunkan tanin dan menstabilkan vitamin $C$ yang terdapat dalam nata de cashew tersebut sehingga nata de cahsew dapat menjadi sumber vitamin $C$ selain sebagai sumber serat.

\section{METODE}

Penelitian yang dilakukan merupakan penelitian dalam bidang produk makanan atau food production dan dilaksanakan di laboratorium Teknologi Pangan UNIMUS untuk pembuatan nata de cashew dan laboratorium Ilmu Pangan Fakultas Teknologi Pertanian UNIKA Soegiejapranata Semarang untuk mengetahui kadar serat dan vitamin C nata de cashew.

Penelitian ini merupakan penelitian eksperimental dengan rancangan acak lengkap satu faktor untuk mengetahui kadar serat, vitamin C, dan tingkat penerimaan nata de cashew dengan 3 perlakuan $\mathrm{pH}$ substrat dan ulangannya $(\mathrm{t}=3)$. Perlakuan dalam penelitian ini dapat dilihat di Tabel 1.

Tabel 1. Perlakuan Nata de Cashew

\begin{tabular}{cccc}
\hline Ulangan & \multicolumn{3}{c}{ Jenis Perlakuan } \\
\cline { 2 - 4 } & $\mathrm{pH} \mathrm{3}$ & $\mathrm{pH} \mathrm{4}$ & $\mathrm{pH} \mathrm{5}$ \\
\hline 1 & $\mathrm{~A} 3$ & $\mathrm{~A} 4$ & $\mathrm{~A} 5$ \\
2 & $\mathrm{~B} 3$ & $\mathrm{~B} 4$ & $\mathrm{~B} 5$ \\
3 & $\mathrm{C} 3$ & $\mathrm{C} 4$ & $\mathrm{C5}$ \\
\hline
\end{tabular}


Bahan yang digunakan dalam penelitian ini adalah buah jambu mete (Anacardium occidentale L.), asam asetat $99 \%$, sumber nitrogen dalam bentuk amonium sulfat komersial yaitu ZA, dan gula tebu putih. Nata de cashew dibuat dengan metode sebagai berikut: pencucian buah $1,5 \mathrm{~kg}$ jambu mete dengan air mengalir kemudian dipotong menjadi kecil-kecil dan diblender dan menambahkan air dengan perbandingan 1:6. ${ }^{10}$ Lalu, jambu mete yang telah diblender diperas menggunakan kain saring. Kemudian dilakukan pencucian buah nanas yang sudah dibersihkan dari kulitnya dengan air mengalir, dipotong kecil-kecil kemudian diblender tanpa air. Penambahan nanas bertujuan untuk mempercepat pertumbuhan bakteri Acetobacter xylinum. Menurut penelitian, dengan perbandingan sari buah nanas dan sari buah jambu mete 1:2, maka didapatkan hasil yang paling tebal. ${ }^{11}$ Setelah itu, sari buah jambu mete ditambahkan gula sebanyak 5\%, ZA $0,4 \%$. Kemudian ditambahkan asam asetat glasial hingga $\mathrm{pH}$ substrat 3, 4, dan 5. Setelah itu, sari buah jambu mete yang telah ditambahkan bahan-bahan tambahan dipanaskan hingga suhu $100^{\circ} \mathrm{C}$ selama 3 menit. Setelah mendidih, cairan sari buah jambu mete dituang ke dalam loyang yang sudah disterilisasi, dan segera ditutup dengan kertas yang sudah disterilkan. Bakteri Acetobacter xylinum merupakan bakteri aerob yang membutuhkan udara untuk dapat tumbuh. ${ }^{8}$ Kertas digunakan untuk menutup substrat agar bersih dan udara tetap bisa masuk untuk bakteri Acetobacter xylinum tumbuh.
Setelah loyang ditutup, kemudian substrat didiamkan hingga dingin atau suhu ruang $25-35^{\circ} \mathrm{C}$. Setelah dingin, cairan diinokulasi dengan menuangkan starter atau bibit nata sebanyak 10\% dari jumlah cairan. Kemudian ditutup kembali dengan kertas dan difermentasi selama 14 hari.

Data yang dikumpulkan yaitu kadar serat, kadar vitamin $\mathrm{C}$, dan tingkat penerimaan nata de cashew. Kadar serat diuji menggunakan metode gravimetri. Kadar vitamin $\mathrm{C}$ diuji menggunakan metode 2,6-diklorofenolindofenol atau yang sering disebut juga metode dye. Tingkat penerimaan menggunakan uji hedonik terhadap warna, aroma, tekstur, dan rasa nata de cashew. Uji dilakukan pada 20 panelis agak terlatih dari mahasiswa semester VIII Program Studi Ilmu Gizi Universitas Diponegoro Semarang menggunakan 5 skala penilaian yaitu 1 = sangat tidak suka, $2=$ tidak suka, $3=$ netral, $4=$ suka, $5=$ sangat suka.

Pengaruh variasi $\mathrm{pH}$ terhadap kadar serat dan vitamin $\mathrm{C}$ nata de cashew diuji statistik menggunakan independent $t$ test dengan derajat kepercayaan $95 \%$, sedangkan tingkat penerimaan diuji dengan Wilcoxon dengan kepercayaan 95\% untuk mengetahui beda nyata antar perlakuan.

\section{HASIL}

\section{Kadar Serat dan Vitamin C pada Nata de Cashew \\ Hasil analisis kadar serat dan vitamin $\mathrm{C}$ pada nata de cashew disajikan pada Tabel 2.}

Tabel 2. Rerata Kadar Serat dan Vitamin C pada Nata de Cashew

\begin{tabular}{ccc}
\hline \multirow{2}{*}{ Perlakuan } & \multicolumn{2}{c}{ Rerata Kandungan Zat Gizi } \\
\cline { 2 - 3 } & Serat $(\%)$ & Vitamin C $(\mathrm{mg} \%)$ \\
\hline pH 3 & - & - \\
pH 4 & $2,59 \pm 1,80^{\mathrm{a}}$ & $42,86 \pm 14,85^{\mathrm{a}}$ \\
$\mathrm{pH} \mathrm{5}$ & $2,71 \pm 0,59^{\mathrm{a}}$ & $42,86 \pm 14,85^{\mathrm{a}}$ \\
\hline & $\mathrm{p}=0,135$ & $\mathrm{p}=1,000$ \\
\hline
\end{tabular}

Keterangan: dihitung berdasarkan uji independen t test.

Berdasarkan Tabel 2, kadar serat pada nata de cashew $\mathrm{pH} 5$ lebih tinggi dari pada nata de cashew dengan $\mathrm{pH} 4$ dan kadar vitamin $\mathrm{C}$ pada nata de cashew $\mathrm{pH} 4$ dan $\mathrm{pH} 5$ adalah sama. Hasil penelitian menunjukkan bahwa tidak ada perbedaan bermakna antara kadar serat dan vitamin $\mathrm{C}$ antara nata de cashew $\mathrm{pH} 4$ dan $\mathrm{pH} 5$.

\section{Kesukaan Nata de Cashew}

Hasil analisis kesukaan warna, aroma, tekstur, dan rasa nata de cashew disajikan dalam Tabel 3.

Tabel 3. Rerata Tingkat Penerimaan Warna, Aroma, Tekstur dan Rasa Nata de Cashew

\begin{tabular}{ccccccccc}
\hline \multirow{2}{*}{ Perlakua } & \multicolumn{2}{c}{ Warna } & \multicolumn{2}{c}{ Aroma } & \multicolumn{2}{c}{ Tekstur } & \multicolumn{2}{c}{ Rasa } \\
\cline { 2 - 8 } neta & Rerata & Ket & Rerata & Ket & Rerata & Ket & Rerata & Ket \\
\hline pH 3 & - & - & - & - & - & - & - & -
\end{tabular}




\begin{tabular}{ccccccccc} 
pH 4 & $2,90 \pm 0,8$ & Netral & $\begin{array}{c}2,40 \pm 0, \\
94^{\mathrm{a}}\end{array}$ & $\begin{array}{c}\text { Tida } \\
\mathrm{k}\end{array}$ & $\begin{array}{c}3,80 \pm 0,62 \\
\text { suka }\end{array}$ & Suka & $3,50 \pm 0,61$ & Suka \\
pH 5 & $\begin{array}{c}1,90 \pm 0,5 \\
5^{\mathrm{a}}\end{array}$ & $\begin{array}{c}\text { Tidak } \\
\text { suka }\end{array}$ & $\begin{array}{c}2,15 \pm 0, \\
81^{\mathrm{a}}\end{array}$ & $\begin{array}{c}\text { Tida } \\
\mathrm{k} \\
\text { suka }\end{array}$ & $\begin{array}{l}3,70 \pm 0,87 \\
\mathrm{a}\end{array}$ & Suka & $3,35 \pm 0,49$ & Netral \\
& $\mathrm{p}=0.000$ & & $\mathrm{p}=0.265$ & & $\mathrm{p}=0.593$ & & $\mathrm{p}=0.257$ & \\
$*$ & & & & & & \\
\hline
\end{tabular}

Keterangan: dihitung berdasarkan uji Wilcoxon

Tabel 3 menunjukkan bahwa tingkat penerimaan warna nata de cashew dengan $\mathrm{pH} 4$ lebih tinggi dari pada nata de cashew dengan pH 5. Kelompok 1-1,49 termasuk kategori sangat tidak suka, kelompok 1,5-2,49 termasuk dalam kategori tidak suka, kelompok 2,5-3,49 tergolong kategori netral, kelompok 3,5-4,49 tergolong kategori suka, dan kelompok 4,5-5 tergolong kategori sangat suka.

Tingkat penerimaan warna nata de cashew $\mathrm{pH}$ 4 yaitu netral sedangkan tingkat penerimaan warna nata de cashew pH 5 adalah tidak suka. Secara statistik terdapat perbedaan bermakna warna nata de cashew $\mathrm{pH} 4$ dan $\mathrm{pH}$ 5. Tingkat penerimaan aroma nata de cashew $\mathrm{pH} 4$ dan $\mathrm{pH} 5$ keduanya tidak disukai oleh panelis. Tingkat penerimaan tekstur nata de cashew $\mathrm{pH} 4$ dan $\mathrm{pH} 5$ keduanya disukai oleh panelis. Secara statistik tidak terdapat perbedaan bermakna antara aroma dan tekstur nata de cashew $\mathrm{pH} 4$ dan $\mathrm{pH}$ 5. Tingkat penerimaan rasa nata de cashew dengan $\mathrm{pH} 4$ lebih tinggi dari pada nata de cashew dengan $\mathrm{pH}$ 5. Tingkat penerimaan nata de cashew $\mathrm{pH} 4$ yaitu suka sedangkan tingkat penerimaan nata de cashew $\mathrm{pH}$ 5 adalah netral. Secara statistik tidak terdapat perbedaan bermakna antara rasa nata de cashew pH 4 dan pH 5.

\section{PEMBAHASAN}

\section{Kadar Serat}

Serat pada nata de cashew berbentuk senyawa selulosa yang dihasilkan melalui proses fermentasi sari buah jambu mete oleh bakteri Acetobacter xylinum. Tanin yang terdapat pada buah jambu mete dapat menghambat pertumbuhan bakteri Acetobacter xylinum. Berdasarkan penelitian, tanin tersebut dapat terhidrolisa melalui proses pengasaman. ${ }^{9,12} \mathrm{pH} 4$ dan 5 termasuk $\mathrm{pH}$ asam yang dapat menginaktifkan kadar tanin, sehingga bakteri Acetobacter xylinum dapat tumbuh dan menghasilkan nata.

Hasil penelitian menunjukkan bahwa kadar serat nata de cashew berkisar antara 1,06\%-4,57\%. Variasi $\mathrm{pH}$ pada proses pembuatan tidak mempengaruhi kadar serat nata de cashew. Meskipun komposisi substrat yang digunakan sesuai dengan acuan yaitu komposisi substrat nata de coco, $\mathrm{pH}$ pada proses pembuatan nata de cashew tidak mempengaruhi kadar serat nata. Kandungan sari buah jambu mete tidak sama dengan air kelapa. Karbon dan nitrogen yang diperlukan untuk perumbuhan Acetobacter xylinum terdapat dalam jambu mete dan air kelapa dalam bentuk karbohidrat dan protein. Kandungan karbohidrat dan nitrogen yang terdapat dalam jambu mete lebih tinggi dibandingkan air kelapa. Sehingga penambahan gula dan ZA pada proses pembuatan nata de cashew tidak dapat disamakan seperti pada pembuatan nata de coco. Hal tersebut mengakibatkan aktivitas pertumbuhan Acetobacter xylinum pada nata de cashew kurang optimal. Perbedaan kandungan unsur gizi dalam buah jambu mete dan air kelapa dapat dilihat pada Tabel 4.

Tabel 4. Kandungan Unsur Gizi dalam Buah Semu Jambu Mete dan Air Kelapa

\begin{tabular}{cccc}
\hline No & Unsur Gizi & \multicolumn{2}{c}{ Kadar per 100 gram bahan } \\
\cline { 3 - 4 } & & Jambu Mete & Air Kelapa \\
\hline 1 & Energi (kal) & 72 & 17 \\
2 & Air $(\mathrm{g})$ & 82,5 & 96 \\
3 & Protein $(\mathrm{g})$ & 0,7 & 0,2 \\
4 & Lemak $(\mathrm{g})$ & 0,6 & 0,1 \\
5 & Karbohidrat $(\mathrm{g})$ & 15,9 & 3,8 \\
7 & Kalsium $(\mathrm{mg})$ & 4 & 15 \\
8 & Fosfor $(\mathrm{mg})$ & 13 & 8
\end{tabular}




$\begin{array}{cccc}9 & \text { Besi (mg) } & 0,5 & 0,2 \\ 10 & \text { Vitamin A (mcg) } & 15 & 0 \\ 11 & \text { Vitamin B (mcg) } & 0,02 & 0 \\ \text { Sumber: Daftar Analisis Bahan Makanan Fak. Kedokteran UI, Jakarta, } 1992 . & 1\end{array}$

Selulosa dapat terhidrolisis oleh asam konsentrasi tinggi sehingga kadar serat nata de cashew pada $\mathrm{pH} 5$ lebih tinggi dibanding $\mathrm{pH} 4$. Sari buah jambu mete dengan $\mathrm{pH} 3$ tidak berhasil berfermentasi menjadi nata de cashew karena $\mathrm{pH}$ tersebut terlalu asam untuk Acetobacter xylinum tumbuh. Bakteri tersebut memiliki sifat hidup pada pH 3,5-7,5. Selulosa yang terbentuk oleh bakteri Acetobacter xylinum juga dapat terhidrolisis oleh asam kuat sehingga dalam $\mathrm{pH} 3$, selulosa sulit terbentuk.

\section{Kadar Vitamin C}

Kadar vitamin C pada nata de cashew diperoleh dari vitamin $\mathrm{C}$ yang terdapat dalam buah semu jambu mete.Vitamin $\mathrm{C}$ atau asam askorbat memiliki sifat mudah larut dalam air dan mudah rusak oleh oksidasi, panas, dan alkali namun stabil pada $\mathrm{pH}$ asam. Analisis kadar vitamin $\mathrm{C}$ didapatkan melalui metode 2,6diklorofenolindofenol atau metode dye.

Kadar vitamin $\mathrm{C}$ nata de cashew dengan variasi $\mathrm{pH}$ berkisar antara 25,71 - 51,43 $\mathrm{mg} \%$. Berdasarkan AKG (Angka Kecukupan Gizi) vitamin $\mathrm{C}$ adalah $60 \mathrm{mg}$ per hari pada orang dewasa. Dengan mengkonsumsi 100 gram nata de cashew, maka telah terpenuhi vitamin $\mathrm{C}$ sebesar $85,72 \%$. Nata de cashew memberikan sumbangan vitamin $\mathrm{C}$ yang cukup besar.

Variasi $\mathrm{pH}$ tidak mempengaruhi kadar vitamin $\mathrm{C}$ nata de cashew. Hal ini disebabkan vitamin $\mathrm{C}$ memiliki sifat stabil dalam suasana asam. ${ }^{13}$ Nata de cashew dengan $\mathrm{pH} 3$ tidak dapat terbentuk sehingga tidak dapat dihitung kadar vitamin $\mathrm{C}$ dari nata de cashew $\mathrm{pH} 3$. Variasi $\mathrm{pH} 4$ dan 5 termasuk $\mathrm{pH}$ asam sehingga vitamin $\mathrm{C}$ yang terdapat dalam substrat nata de cashew dengan variasi $\mathrm{pH} 4$ dan 5 tetap stabil dan tidak mempengaruhi kadar vitamin $\mathrm{C}$ dalam substrat.

Vitamin C mudah rusak dalam panas. Pada pembuatan nata de cashew terdapat proses perebusan sebelum fermentasi dengan suhu $100^{\circ} \mathrm{C}$ (mendidih) untuk mensterilkan substrat nata, mengakibatkan vitamin $\mathrm{C}$ mengalami kerusakan. Dalam pembuatan nata de cashew, sari buah jambu mete juga diencerkan dengan air sehingga kadar vitamin $\mathrm{C}$ pada nata de cashew berkurang. Buah jambu mete mengandung $197 \mathrm{mg} \%$ vitamin C, sehingga nata de cashew mengalami penurunan kadar vitamin $\mathrm{C}$ jika dibandingkan dengan bahan bakunya yaitu sekitar 73,6-87,3\%.

3. Tingkat penerimaan

a. Warna

Warna yang dihasilkan oleh nata de cashew adalah putih kecokelatan. Warna yang terbentuk pada nata de cashew dipengaruhi oleh warna dari sari buah jambu mete dan $\mathrm{pH}$. Berdasarkan penelitian nata de pina oleh Muchtadi, warna nata yang terbentuk adalah putih, namun berkaitan dengan adanya vitamin $\mathrm{C}$ pada penelitian ini diduga dapat memberikan warna nata putih kecokelatan. ${ }^{14}$

Warna coklat pada nata de cahsew terbentuk karena buah jambu mete yang menjadi bahan dasar dalam pembuatan nata de cashew memiliki kandungan vitamin $\mathrm{C}$ yang tinggi. Vitamin $\mathrm{C}$ merupakan suatu senyawa reduktor dan juga dapat bertindak sebagai precusor untuk pembentukan warna cokelat nonenzimatik. ${ }^{13}$ Warna coklat pada nata de cashew merupakan hasil oksidasi vitamin C.

Warna nata de cashew pH 4 lebih terang dari pada nata de cashew dengan pH 5. Hal tersebut disebabkan oleh sifat vitamin $\mathrm{C}$ yang lebih stabil pada $\mathrm{pH}$ rendah sehingga menyebabkan nata de cashew pH 5 lebih teroksidasi dan berwarna lebih cokelat. Panelis lebih menyukai warna nata de cashew $\mathrm{pH} 4$ dari pada nata de cashew dengan $\mathrm{pH} 5$.

b. Aroma

Pada penelitian ini, nata de cashew $\mathrm{pH} 4$ dan $\mathrm{pH} 5$ memiliki penilaian tidak suka. Aroma nata de cashew yang baru dipanen sangat asam. ${ }^{15}$ Panelis tidak menyukai aroma dari nata de cashew $\mathrm{pH}$ 4 maupun $\mathrm{pH}$ 5. Variasi $\mathrm{pH}$ tidak berpengaruh terhadap aroma nata de cashew.

Nata de cashew yang baru dipanen memiliki aroma asam yang sangat tajam. Setelah dipanen, nata de cashew dicuci pada air mengalir kemudian direndam 
selama 2 hari (air rendaman diganti setiap 12 jam) dan direbus untuk mengurangi aroma asam. Aroma asam nata de cashew $\mathrm{pH} 4$ dan $\mathrm{pH} 5$ berkurang tetapi tidak hilang seluruhnya. Untuk mengurangi aroma asam tersebut, dapat ditambahkan vanili atau ekstrak buah. Selulosa tidak memiliki aroma. Aroma yang dihasilkan nata de cashew berasal dari buah jambu mete dan bakteri Acetobacter xylinum.

c. Tekstur

Variasi $\mathrm{pH}$ tidak mempengaruhi tekstur nata de cashew. Tekstur nata de cashew baik $\mathrm{pH} 4$ dan $\mathrm{pH} 5$ keduanya disukai oleh panelis dan keduanya tidak memiliki perbedaan. Tektur yang dihasilkan adalah padat dan kenyal. Hal ini dipengaruhi oleh kadar serat dan air yang terdapat dalam nata de cashew tersebut. Semakin tinggi kadar serat, maka semakin kenyal tekstur nata de cashew tersebut. Semakin tinggi ketebalan selulosa yang dihasilkan, semakin banyak air yang mengisi ronggarongga antar selulosa sehingga kekenyalannya semakin berkurang.

Dalam proses pembuatan nata de cashew, ditambahkan $60 \mathrm{~mL}$ sari buah nanas. Sari buah nanas memliki kandungan asam-asam organik dan mineral yang dibutuhkan oleh bakteri Acetobacter xylinum untuk mempercepat aktivitas pertumbuhannya. Buah jambu mete dan nanas memiliki kandungan karbohidrat dan vitamin $\mathrm{C}$ yang lebih tinggi dari pada air kelapa.

d. Rasa

Rasa yang dihasilkan nata de cashew adalah tawar. Selulosa tidak memiliki rasa. Nata de cashew disajikan kepada panelis tanpa larutan sukrosa sehingga penyajian nata tidak sesuai dengan penyajian konsumsi nata pada umumnya.

Pembuatan nata de cashew dilakukan proses pemanasan dan pengasaman yang dapat mengurangi kadar tanin. Menurut penelitian, kadar tanin juga dapat berkurang melalui proses fermentasi. ${ }^{16}$ Hal tersebut menyebabkan rasa sepat akibat tanin yang sebelumnya terdapat dalam buah semu jambu mete tidak muncul pada nata de cashew.
Nata de cashew yang disajikan kepada panelis dalam bentuk dadu. Panelis menyukai rasa nata de cashew $\mathrm{pH}$ 4 namun memilih netral untuk nata de cashew pH 5. Kesukaan panelis terhadap rasa nata de cashew $\mathrm{pH} 4$ dan $\mathrm{pH} 5$ tidak memiliki beda nyata.

\section{SIMPULAN}

1. Perlakuan $\mathrm{pH}$ substrat 3 pada pembuatan nata tidak dapat membentuk nata.

2. Variasi $\mathrm{pH}$ tidak mempengaruhi kadar serat nata de cashew. Nata de cashew dengan pH 5 memiliki kandungan serat yang lebih tinggi dibandingkan dengan nata de cashew $\mathrm{pH} 4$. Nata de cashew dapat digunakan sebagai sumber serat dengan memberikan rata-rata $2,81 \%$ serat kasar dalam setiap 100 gram nata de cashew.

3. Variasi $\mathrm{pH}$ tidak mempengaruhi kadar vitamin $\mathrm{C}$ nata de cashew. Nata de cashew dengan $\mathrm{pH}$ 4 dan nata de cashew dengan pH 5 memiliki kandungan vitamin $\mathrm{C}$ yang sama. Nata de cashew dapat digunakan sebagai sumber vitamin $C$ dengan memberikan $85,72 \%$ dalam setiap 100 gram nata de cashew.

4. Pengaruh $\mathrm{pH}$ terhadap tingkat penerimaan nata de cashew:

a. Warna nata de cashew $\mathrm{pH} 4$ lebih dapat diterima oleh panelis karena warnanya yang lebih terang dari pada nata de cashew pH 5.

b. Aroma nata de cashew yang dihasilkan kurang sedap. Variasi $\mathrm{pH}$ tidak mempengaruhi aroma dari nata de cashew.

c. Tekstur nata de cashew yang dihasilkan kenyal. Panelis menyukai tekstur nata de cashew $\mathrm{pH} 4$ dan $\mathrm{pH}$ 5. Variasi $\mathrm{pH}$ tidak mempengaruhi tekstur dari nata de cashew.

d. Rasa nata de cashew tawar dan tidak terasa rasa sepat yang sebelumnya terdapat pada buah semu jambu mete. Variasi $\mathrm{pH}$ tidak mempengaruhi rasa nata de cashew.

\section{SARAN}

1. Komposisi substrat nata de cashew sebaiknya disesuaikan dengan kandungan jambu mete untuk mengoptimalkan aktivitas pertumbuhan bakteri Acetobacter xylinum.

2. Untuk mengurangi aroma nata de cashew yang kurang sedap dapat dilakukan penambahan vanili atau ekstrak buah agar lebih dapat diterima oleh masyarakat.

3. Penyajian nata de cashew kepada panelis sebaiknya diberikan bersama dengan larutan 
gula 5\% agar lebih sesuai dengan penyajian konsumsi nata pada umumnya.

\section{DAFTAR PUSTAKA}

1. Lies S. Manisan Kering Jambu Mete. Yogyakarta: Kanisius; 2003: 12-20

2. Jahari A.B, Sumarno I. Epidemiologi Konsumsi Serat di Indonesia. Majalah Gizi Indonesia; 2001; 25: p. 37-56.

3. Daftar Analisis Bahan Makanan. Jakarta: Fak. Kedokteran UI; 1992

4. Warsino S, Dahana K. Inspirasi usaha membuat aneka nata. Jakarta: Agromedia Pustaka; 2009.

5. Deddy Muchtadi. Sayuran Sebagai Sumber Sera Pangan Untuk Mencegah Timbulnya Penyakit Degeneratif. Bogor: Jurnal Teknologi dan Industri Pangan Vol. VIII; 2001.

6. Jahari A.B, Sumarno I. Epidemiologi Konsumsi Serat di Indonesia. Majalah Gizi Indonesia; 2001; 25: p. 37-56.

7. Departemen Kesehatan Republik Indonesia. Laporan Hasil Riset Kesehatan Dasar (riskesdas) Indonesia Tahun 2007. Jakarta: Badan Penelitian dan Pengembangan Kesehatan; 2008.

8. Pambayun R. Teknologi Pengolahan Nata de Coco. Yogyakarta: Kanisius; 2002.

9. Wiwik Wijaningsih, Arintina Rahayuni, Sri Hetty Susetyorini. Daya Antiseptik, Kadar Vitamin C, Kadar Tanin, dan Daya Terima Sari Buah Jambu Monyet Pada Jenis Jambu dan Variasi Pengolahan. Semarang: Jurnal Poltekkes Semarang; 2010.

10. Aminah Asngad. Pemanfaatan Lidah Buaya (Aloe vera) Menjadi Produk Makanan Berserat Dengan Penambahan Berbagai Jenis Gula. Surakarta: Jurusan Penelitian Sains dan Teknologi Vol IX; 2008.

11. Feri Manoi. Penambahan Ampas Ekstrak Nenas Sebagai Medium Campuran Pada Pembuatan Nata De Cashew. Buletin Littro 2007; 18; p. 107-116.

12. Ann E. Haggerman. The Tannin Book. USA: Miami University. 2002.

13. F.G. Winarno. Kimia Pangan dan Gizi. Jakarta: PT. Garamedia; 2002: p.131-33.

14. Tien R. Muchtadi. Pangan: Nata de Pina. Jakarta: Swadaya; 1997.

15. Misgiyarta. Agroinovasi Produksi Nata de Cassava Dengan Substrat Limbah Cair Tapioka. Sinartani 2011; 3428; p. 14-15.

16. Yudi Pranoto, Priyanto Triwitono. Peningkatan Kecernaan Pati dan Perubahan Karakteristik Tepung Sorgum dengan Proses Fermentasi. Yogyakarta: Universitas Gadjah Mada; 2010. 